\title{
TINGKAT KERUSAKAN DAN KARBON MANGROVE DENGAN PENDEKATAN DATA SATELIT NDVI (NORMALIZED DIFFERENCE VEGETATION INDEX) DI DESA SIDODADI KABUPATEN PESAWARAN PROVINSI LAMPUNG
}

\author{
Rimty Mayuftia, Agus Hartoko, Boedi Hendrarto ${ }^{I}$ \\ Program Studi Manajemen Sumberdaya Perairan, Jurusan Perikanan \\ Fakultas Perikanan dan Ilmu Kelautan, Universitas Diponegoro
}

\begin{abstract}
ABSTRAK
Ekosistem mangrove sebagaimana ekosistem hutan lainnya memiliki peran sebagai penyerap dan penyimpan karbon guna pengurangan kadar $\mathrm{CO}_{2}$ di udara. Hutan mangrove merupakan komponen penyusun utama dalam ekosistem mangrove. Pesisir Lampung di Desa Sidodadi, Ringgung, Kabupaten Pesawaran, Provinsi Lampung terdapat ekosistem mangrove yang masih asli dan sebagian telah dikonversi menjadi tambak udang dan pemukiman sehingga sebagian telah rusak karena alasan tersebut. Kerusakan vegetasi mangrove dapat diketahui dengan cara menggunakan kriteria yang digunakan untuk mengindikasi adanya kerusakan tegakan mangrove dengan mengunakan data citra landsat yang mencerminkan besaran nilai NDVI (Normalized Difference Vegetation Index).

Penelitian ini menggunakan metode penelitian survei yang bersifat deskriptif, penelitian diarahkan untuk mendeskripsikan atau menguraikan suatu keadaan. Pengambilan data menggunakan metode purposive sampling. Variabel data utama yang dibutuhkan yaitu : Citra Satelit Landsat TM 2012 untuk dianalisis nilai digital number dengan proses dengan ER Mapper, data jenis spesies mangrove, data diameter pohon mangrove untuk data pengolahan biomassa karbon mangrove, kerapatan pohon mangrove, dan koordinat untuk analisa hubungan antara biomassa mangrove, tegakan pohon, dengan NDVI.

Hasil dari penelitian ini menunjukkan bahwa tingkat kerusakan ekosistem mangrove di Pesisir Lampung, Desa Sidodadi, Kabupaten Pesawaran, Provinsi Lampung berdasarkan kriteria nilai NDVI (Normalized Difference Vegetation Index) sebesar 0,25 dan 0,378, tergolong rusak berat dan rusak sedang. Namun berdasarkan baku mutu suatu ekosistem mangrove dengan menggunakan kerapatan pohon dengan interpretasi citra menggunakan Landsat TM dengan kerapatan pohon 880 - >1100 pohon, dikategorikan sangat rapat. Biomassa karbon mangrove terkandung pada vegetasi mangrove yang ada di Pesisir Lampung, Desa Sidodadi, Kabupaten Pesawaran, Provinsi Lampung yaitu 10.694.870,18 kg/ha. Analisa hubungan antara biomassa mangrove dengan nilai NDVI memiliki hubungan yang kuat, namun hubungan pohon mangrove dengan nilai NDVI memiliki nilai hubungan yang rendah.
\end{abstract}

Kata kunci : NDVI (Normalized Difference Vegetation Index), Satelit, Biomassa Karbon Mangrove.

\section{ABSTRACT}

Mangrove ecosystem has a role as absorbing and saving carbon for reducing $\mathrm{CO}_{2}$ in the open air. A natural mangrove ecosystem exists at Lampung Coastal in Sidodadi Village, Pesawaran Region, Lampung Province but it has been already converted to shrimp farm and for settlement. The damage of mangrove ecosystem maybe analized with digital number of NDVI (Normalized Difference Vegetation Index) from satellite data.

The method of the research was descriptive survey method for describing the situation. The samples used purposive sampling method. The main variable data was needed : Satellite data Landsat TM 2012 for analizing digital number to be prossed in ER Mapper program, spesies mangrove, trunk diameter of mangrove for measuring mangrove carbon biomass, mangrove density, and coordinat for analizing correlation of mangrove biomass, mangrove density, and NDVI.

The result of this research was the damage level of mangrove ecosystem Lampung Coastal in Sidodadi Village, Pesawaran Region, Lampung Province as NDVI (Normalized Difference Vegetation Index) was 0,25 and 0,378 , the meaning of the digital number for the criteria was damage and medium. Criteria density and GIS (Geographic Information System) Landsat TM, the vegetation has 880 - >1100 trees, was categorized very dense. Mangrove carbon biomass Lampung Coastal, Sidodadi Village, Pesawaran Region, Lampung Province is $10.694 .870,18 \mathrm{kgs} / \mathrm{ha}$. The analysis of Mangrove biomass was proved to be correlation with NDVI, but density of mangrove tree with NDVI has not showed the significant correlation.

Keywords : NDVI (Normalized Difference Vegetation Index), Sattelite Data, Mangrove Carbon Biomass.

*) Penulis Penanggung Jawab 


\section{Pendahuluan}

Pesisir Lampung di Desa Sidodadi, Ringgung, Kabupaten Pesawaran, Provinsi Lampung terdapat ekosistem mangrove yang masih asli dan sebagian telah dikonversi menjadi tambak udang dan pemukiman sehingga sebagian telah rusak karena alasan tersebut.

Ekosistem mangrove sebagaimana ekosistem hutan lainnya memiliki peran sebagai penyerap dan penyimpan karbon guna pengurangan kadar $\mathrm{CO}_{2}$ di udara. Hutan mangrove merupakan komponen penyusun utama dalam ekosistem mangrove. Hutan mangrove menyimpan banyak karbon dibanding kebanyakan hutan hujan tropis. Selain itu kerusakan hutan mangrove akan menurunkan kemampuan alamiahnya untuk menyerap dan menyimpan karbon.

Ekosistem mangrove potensial mendapatkan tekanan dari kegiatan manusia dan pembangunan, terlebih lagi pesisir merupakan wilayah dengan tingkat aktivitas perekonomian tinggi. Oleh sebab itu tekanan untuk konversi kawasan mangrove untuk budidaya perairan, infrastruktur pantai pelabuhan, industri, pusat perdagangan dan perumahan, pemanfaatan kayu hutan, pertanian, dan perikanan juga sangat tinggi. Akan tetapi penyebab utama yang paling besar adalah konversi mangrove menjadi kawasan budidaya yang tidak terkendali (Departemen Kelautan dan Perikanan, Direktorat Bina Pesisir, Ditjen KPPK, 2007).

Kerusakan vegetasi mangrove dapat diketahui dengan cara menggunakan kriteria yang digunakan untuk mengindikasi adanya kerusakan tegakan mangrove dengan mengunakan data citra landsat yang mencerminkan besaran nilai NDVI (Normalized Difference Vegetation Index).

Penggunaan teknologi pengindraan jauh merupakan salah satu alternatif yang perlu dikaji untuk mendapatkan informasi tentang suatu wilayah karena teknologi ini mempunyai beberapa keunggulan dibandingkan pengumpulan data secara konvensionl. Dalam hal ini dilakukan penelitian di Pesisir Lampung, Desa Sidodadi, Ringgung, Kabupaten Pesawaran, Provinsi Lampung dengan menggunakan data lapangan dan data citra satelit Landsat. Pemanfaatan metode pengindraan jauh dengan menggunakan data citra satelit dapat memperoleh data lebih cepat dalam waktu bersamaan dengan cakupan yang luas.

Tujuan dari penelitian ini adalah untuk mengetahui biomassa karbon yang terkandung pada vegetasi mangrove, tingkat kerusakan ekosistem mangrove di Pesisir Lampung, Desa Sidodadi, Kabupaten Pesawaran, Provinsi Lampung berdasarkan kriteria nilai NDVI (Normalized Difference Vegetation Index) menggunakan data citra satelit Landsat-TM, dan menganalisa adanya hubungan antara Biomassa Karbon dan Nilai NDVI (Normalized Difference Vegetation Index). Kegiatan penelitian ini dilaksanakan pada Maret 2013 di Pesisir Lampung, Desa Sidodadi, Kabupaten Pesawaran, Provinsi Lampung. Terdapat dua lokasi penelitian, yaitu: Zona I pada kordinat 5032'26' - 5 $5^{0} 33^{\prime} 1^{\prime}$ ' LS dan $105^{\circ} 15^{\prime} 17^{\prime \prime}$ - $105^{\circ} 15^{\prime} 9^{\prime}$ ' BT. Zona II

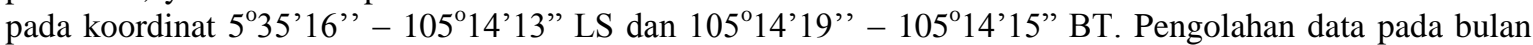
April - September 2013 di Laboratorium Inderaja Perikanan Fakultas Perikanan dan Ilmu Kelautan Universitas Diponegoro, Semarang.

\section{Materi dan Metode Penelitian}

\section{A. Materi Penelitian}

Materi yang digunakan dalam penelitian ini adalah berupa variabel utama dan variabel penunjang. Variabel utama yang dibutuhkan yaitu : Citra Satelit Landsat TM 2012, data jenis spesies mangrove, data diameter pohon mangrove, kerapatan pohon mangrove, dan koordinat. Variabel penunjang berupa data substrat, suhu dan salinitas. Identifikasi mangrove menggunakan Buku Panduan Pengenalan Mangrove di Indonesia (Noor, et al, 2006). Data koordinat pengambilan sampel menggunakan GPS (Global Positioning System). Proses data citra menggunakan software ER Mapper 7.0. Analisa hubungan antar variabel menggunakan software SPSS ver. 16.

\section{B. Metode Penelitian}

Berdasarkan tujuan untuk memperoleh fakta dari permasalahan dan penelitian diarahkan untuk mendeskripsikan atau menguraikan suatu keadaan, maka penelitian menggunakan metode penelitian survei yang bersifat deskriptif (Nazir, 1983; Hadi, 1984).

\section{Pengambilan sampel lapangan}

Desain dari sampling vegetasi mangrove merupakan metode sampling vegetasi mangrove dilakukan dengan menggunakan modifikasi metode plot sampling yang diterapkan oleh Mueller-Dumbois dan Ellenberg (1974) yaitu plot berukuran $10 \mathrm{~m}$ x $10 \mathrm{~m}$ yang berarti luasnya $100 \mathrm{~m}^{2}$ termasuk dalam menghitung untuk anakan (sapling) dan semai (seedling) (Hendrarto, 2013 pers.com). Data yang diambil tersebut dianalisa untuk diketahui nilai Frekuensi kehadiran Kerapatan (K). Penelitian ini dibagi menjadi 2 stasiun atau disebut Zona dengan pertimbangan struktur vegetasi mangrove dari kedua lokasi penelitian berbeda.

\section{Pengambilan Data Biomassa Karbon Vegetasi Mangrove}

Pengambilan data untuk perhitungan kandungan karbon dalam penelitian ini dilakukan di atas permukaan tanah yaitu bagian lingkar batang. Prosedur dalam pengukuran kandungan karbon pohon dilakukan dengan cara non destruktif (tidak merusak tanaman) dengan catatan jenis tanaman yang diukur sudah diketahui rumus allometrik. 
Pengolahan dan Analisis Data

a. Perhitungan Biomassa Karbon

Analisis pendugaan karbon tanaman mangrove di atas permukaan tanah menggunakan algoritma berdasarkan spesies tanaman adalah sebagai berikut :

a. Avicennia alba menurut Siregar dan Dharmawan (2009).

$\mathrm{W}=0.2901(\mathrm{DBH})^{2.2605}$

b. Rhizopora apiculata dan Rhizopora stylosa menurut Clough dan K. Scott (1989).

$\mathrm{W}=0.9789 \mathrm{DBH}^{2.6848}$

c. Persamaan alometrik biomassa di atas tanah Rhizopora mucronata menurut Amarashige dan Balasubramianum (2005) dalam Temilola, et al (2007).

$\mathrm{W}=0.251 \times 0.701\left(\mathrm{D}^{2.46}\right)$

d. Persamaan alometrik biomassa di atas tanah Sonneratia alba menurut Komiyama, et al (2005) dalam Temilola, et al (2007).

$\mathrm{W}=0.251 \times 0.475\left(\mathrm{D}^{2.46}\right)$

e. Bruguiera parviflora menurut Clough dan K. Scott (1989). $\mathrm{W}=0.7749 \mathrm{DBH}^{2.4167}$

f. Persamaan alometrik biomassa untuk Hutan Tanaman Mangrove menurut Siregar dan Darmawan (2009).

$\mathrm{W}=0.2064(\mathrm{DBH})^{2.34}$

Keterangan:

$\mathrm{W}=$ Berat Total Karbon di Atas Permukaan Tanah

$\mathrm{DBH}=$ Diameter pohon setinggi dada $(\mathrm{cm})$

\section{b. Perhitungan Data Vegetasi Mangrove}

Dalam vegetasi dianalisis berdasarkan dengan menggunakan metode Mueller-Dumbois dan Ellenberg (1974), yaitu:

1. Kerapatan $(\mathrm{K})$

Satuan kerapatan yang digunakan dalam penelitian vegetasi mangrove ini adalah individu/hektar (ind/ha).

$\mathrm{K}($ spesies $\mathrm{A})=\frac{\text { Jumlah individu spesies A }}{\text { Luas area yang diteliti (ha) }}$

2. Kerapatan Relatif (KR)

Kerapatan relatif merupakan presentase kerapatan masing-masing spesies dalam transek. Nilai kerapatan relatif didapatkan dengan menggunakan rumus (English et al, 1997)

Keterangan:

$$
\mathrm{KR}=100 \%(\mathrm{ni} / \mathrm{N})
$$

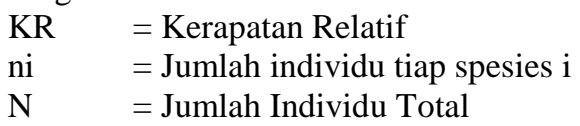

\section{c. Analisa Hubungan Kerusakan Mangrove dengan Nilai NDVI}

Nilai digital dari Normalized Difference Vegetation Index (NDVI) dapat memperkirakan suatu vegetasi mangrove di suatu wilayah tertentu. Keadaan vegetasi dapat diketahui secara menyeluruh dari hasil NDVI tersebut.

Analisa kerusakan mangrove dengan data citra satelit yang dilakukan dengan mengolah dalam software ER Mapper 7.0. Analisis NDVI (Normalized Difference Vegetation Index) vegetasi Mangrove dilakukan dengan memunculkan RGB (Red Green Blue) dengan band 3, band 4 dan band 5. Langkah ini bertujuan membedakan vegetasi mangrove dengan tumbuhan terestial yang lainnya. Kemudian dalam algoritnm ditentukan indeks NDVI (Normalized Difference Vegetation Index) (Hartoko, A. dan M. Helmi, 2008) dengan memasukkan (input) rumus matematis sebagai berikut:

$$
\text { NDVI }=\frac{\text { band } 3 \text {-band } 4}{\text { band } 3+\text { band } 4}
$$

Hasil dari NDVI berupa digital number disesuaikan dengan koordiant lapangan. Nilai NDVI menentukan tingkat dari kerusakan vegetasi mangrove. Menurut Kusmana (2010) tingkat kerusakan mangrove dalam hubungannya dengan nilai NDVI dan cover density dapat dilihat pada tabel berikut.

Tabel 1. Tingkat Kerusakan Mangrove Berdasarkan Nilai NDVI dan Kerapatan Kanopi

\begin{tabular}{ccc}
\hline Kelas Kerusakan Mangrove & Kisaran Nilai NDVI & Estimasi Kerapatan Kanopi \\
\hline Berat & $(-1)-(0,32)$ & $<50 \%$ \\
Sedang & $(0,32)-(0,42)$ & $50-70 \%$ \\
Tidak Rusak & $(0,42)-(+1)$ & $>70 \%$ \\
\hline
\end{tabular}

Sumber: Kusmana (2010). 


\section{d. Analisis hubungan antar biomassa karbon mangrove dengan nilai NDVI (Normalized Difference} Vegetation Index)

Hubungan antara biomassa karbon mangrove dengan nilai NDVI (Normalized Difference Vegetation Index) dianalisis dengan uji regresi. Uji regresi merupakan metode matematis yang dapat digunakan untuk mengetahui pola hubungan antar variable dan membuat persamaan estimasi dari variable tersebut (Sudjana, 1992).

\section{Hasil dan Pembahasan}

\section{Kondisi Umum Lokasi Penelitian}

Lokasi penelitian terletak bagian pesisir di sebelah timur Desa Sidodadi. Secara administrasi lokasi penelitian termasuk dalam Kecamatan Padang Cermin, Kabupaten Pesawaran, Provinsi Lampung. Lokasi penelitian berada di kawasan pemukiman warga di Desa Sidodadi dan di sekitar daerah penelitian terdapat pertambakan udang dan karamba jaring apung ikan kerapu milik pihak swasta.

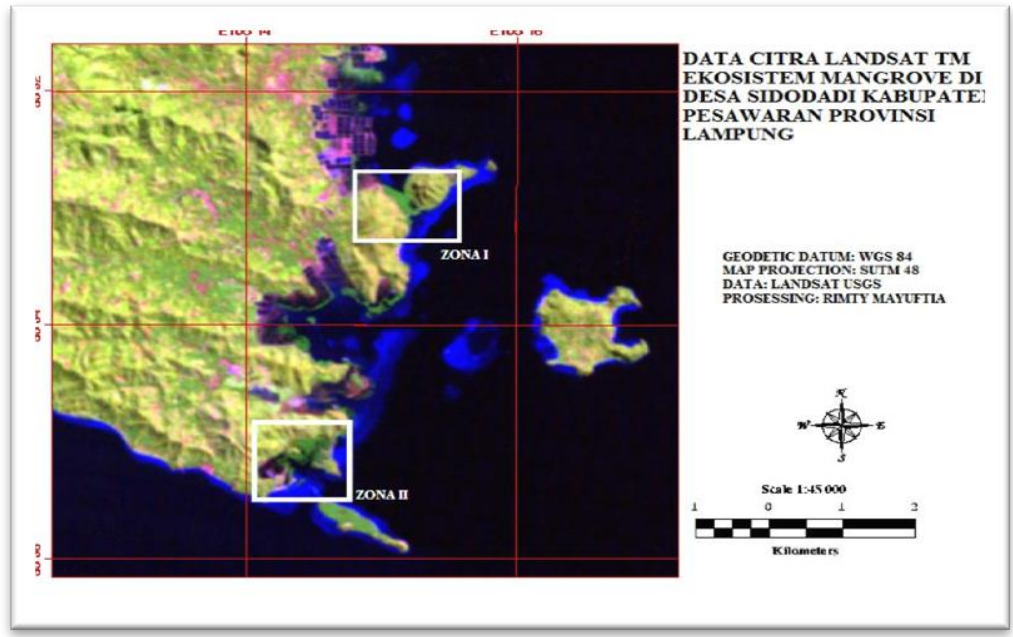

Gambar 1. Peta Daerah Penelitian Zona I dan Zona II Ekosistem Mangrove di Desa Sidodadi, Ringgung, Jenis Mangrove Kabupaten Pesawaran, Provinsi Lampung Data Citra Satelit Landsat TM.

Pada Zona I terdapat berbagai jenis yang mangrove sejati (true mangrove) dan mangrove ikutan atau mangrove asosiasi. Mangrove sejati terdiri dari Rhizopora apiculata, Rhizopora stylosa, Rhizopora mucronata, Sonneratia alba, Ceriops tagal, Lumnitzera littorea dan Bruguiera parviflora. Terdapat pula jenis mangrove asosiasi yaitu Thespesia populnea, dan Excoecaria agalocha. Pada Zona II didominasi hanya oleh mangrove sejati seperti Rhizophora apiculata, Rhizophora stylosa, Rhizopora mucronata, Lumnitzera littorea, dan Sonneratia alba. Jenis keanekaragaman mangrove pada Zona I lebih banyak dari pada komposisi mangrove pada Zona II.

Tabel 2. Tipe dan Nama Spesies Mangrove pada Zona I dan Zona II.

\begin{tabular}{clc}
\hline Tipe Mangrove & \multicolumn{1}{c}{ Spesies pada Zona I } & \multicolumn{1}{c}{ Spesies pada Zona II } \\
\hline Mangrove Sejati & Rhizophora apiculata & Rhizophora stylosa \\
& Rhizophora stylosa & Rhizophora apiculata \\
& Rhizopora mucronata & Rhizopora mucronata \\
& Sonneratia alba & Sonneratia alba \\
& Ceriops tagal & - \\
& Bruguiera parviflora & - \\
& Avicennia marina & - \\
& Lumnitzera littorea & - \\
Mangrove Asosiasi & Thespesia populnea & - \\
& Excoecaria agalocha & - \\
\hline
\end{tabular}

\section{Vegetasi Mangrove}

a. Pohon

Kepadatan individu pada Zona I paling banyak dari Rhizophora apiculata dengan nilai Kerapatan (K) memiliki 1296 individu per hektar dengan nilai presentase kehadiran sebanyak 58,9\% dari seluruh spesies mangrove di Zona I. Kepadatan spesies terendah pada Avicennia marina dengan nilai Kerapatan hanya 3 individu per hektar. 
http://ejournal-sl.undip.ac.id/index.php/maquares

Tabel 3. Nilai Kerapatan, dan Kerapatan Relatif Spesies Mangrove pada Zona I

\begin{tabular}{lcc}
\hline \multicolumn{1}{c}{ Spesies Mangrove } & Kerapatan (K) (ind/ha) & Kerapatan Relatif (KR) \\
\hline Rhizophora apiculata & 1296 & $58,9 \%$ \\
Rhizophora stylosa & 393 & $17,9 \%$ \\
Rhizopora mucronata & 13 & $0,6 \%$ \\
Sonneratia alba & 83 & $3,8 \%$ \\
Ceriops tagal & 133 & $6,1 \%$ \\
Bruguiera parviflora & 16 & $0,8 \%$ \\
Avicennia marina & 3 & $0,2 \%$ \\
Thespesia populnea & 140 & $6,4 \%$ \\
Excoecaria agalocha & 46 & $2,1 \%$ \\
Lumnitzera littorea & 73 & $3,3 \%$ \\
\hline Jumlah Individu & 660 &
\end{tabular}

Kerapatan (K) dan Kerapatan Relatif (KR) pada Zona II masih didominasi oleh Rhizopora apiculata dan Rhizopora stylosa. Namun, pada Zona II nilai K dan nilai KR paling dominan adalah dari spesies Rhizopora stylosa dengan nilai K sebesar $61.8 \%$ dan nilai dari KR sebesar 55.4\%. Pada Zona II tidak terdapat mangrove asosiasi seperti pada Zona I dan jumlah kerapatan spesies dilihat dari jumlah pohon, lebih banyak pada Zona II yaitu sebesar 1115 individu mangrove. Namun, dari aspek keanekaragaman spesies. Zona I memiliki spesies mangrove yang lebih bervariasi.

Tabel 4. Nilai Kerapatan, dan Kerapatan Relatif Spesies Mangrove pada Zona II

\begin{tabular}{lcc}
\multicolumn{1}{c}{ Spesies Mangrove } & Kerapatan $(\mathrm{K})(\mathrm{ind} / \mathrm{ha})$ & Kerapatan Relatif $(\mathrm{KR})$ \\
\hline Rhizophora apiculata & 1453 & $39,1 \%$ \\
Rhizophora stylosa & 2060 & $55,4 \%$ \\
Rhizopora mucronata & 156 & $4,2 \%$ \\
Sonneratia alba & 46 & $1,3 \%$ \\
\hline Jumlah Individu & 1115 &
\end{tabular}

\section{b. Sapling}

Zona I sapling atau anakan paling banyak oleh jenis mangrove Rhizopora stylosa dengan nilai kerapatan sebesar 303 individu per hektar dan nilai KR sebesar 45,73\%. Sedangkan untuk mangrove asosiasi terdapat Lumnitzera littorea yang mempunyai nilai kerapatan sebesar 33 individu per hektar dan nilai KR sebesar 5,03\% dari total sapling yang ada pada Zona I. Sapling pada Zona II memiliki nilai kerapatan dan KR terbesar seperti pada katagori pohon pada Zona II yaitu Rhizopora stylosa dengan nilai berturut-turut adalah 1296 individu per hektar dan presentase sebesar $91,75 \%$.

\section{Pendugaan Biomassa Karbon pada Mangrove}

Pendugaan biomassa karbon yang terdapat pada Zona I dan Zona II adalah sebagai berikut :

Tabel 5. Spesies Mangrove dengan Diameter Pohon dan Biomassa Karbon pada Zona I.

\begin{tabular}{lcc}
\hline \multicolumn{1}{c}{ Spesies Mangrove } & $\varnothing$ Pohon $( \pm$ SD cm) & Biomassa $( \pm$ SD kg) \\
\hline Rhizophora apiculata $(\mathrm{n}=389)$ & $7,52 \pm 6,24$ & $1.622 .150,44 \pm 4.230,62$ \\
Rhizophora stylosa $(\mathrm{n}=118)$ & $13,76 \pm 6,95$ & $722.880,54 \pm 2.916,30$ \\
Rhizopora mucronata $(\mathrm{n}=4)$ & $16,40 \pm 2,67$ & $2.624,97 \pm 76,87$ \\
Sonneratia alba $(\mathrm{n}=25)$ & $31,97 \pm 15,64$ & $74,976.16 \pm 999,33$ \\
Ceriops tagal $(\mathrm{n}=40)$ & $9,87 \pm 5,56$ & $6433,59 \pm 136,34$ \\
Bruguiera parviflora $(\mathrm{n}=5)$ & $15,67 \pm 10,51$ & $16.775,07 \pm 1.676,42$ \\
Avicennia marina $(\mathrm{n}=1)$ & 20,38 & 881,02 \\
Thespesia populnea $(\mathrm{n}=42)$ & $13,69 \pm 15,70$ & $107.689,71 \pm 1.284,93$ \\
Excoecaria agalocha $(\mathrm{n}=14)$ & $26,48 \pm 9,57$ & $24.573,83 \pm 380,42$ \\
Lumnitzera littorea $(\mathrm{n}=22)$ & $24,29 \pm 11,42$ & $35.444,55 \pm 532,43$ \\
\hline
\end{tabular}

Keterangan: $\varnothing$ diameter pohon

Tabel 6. Spesies Mangrove dengan Diameter Pohon dan Biomassa Karbon pada Zona II.

\begin{tabular}{lcc}
\hline \multicolumn{1}{c}{ Spesies Mangrove } & $\varnothing$ Pohon $( \pm$ SD cm $)$ & Biomassa $( \pm$ SD kg) \\
\hline Rhizophora apiculata $(\mathrm{n}=436)$ & $15,56 \pm 8,82$ & $4.012 .238,35 \pm 6.450,09$ \\
Rhizophora stylosa $(\mathrm{n}=618)$ & $12,65 \pm 7,12$ & $3.994 .625,68 \pm 15.873,56$ \\
Rhizopora mucronata $(\mathrm{n}=47)$ & $20,02 \pm 11,01$ & $70.636,66 \pm 918,89$ \\
Sonneratia alba $(\mathrm{n}=14)$ & $31,37 \pm 15,55$ & $39.265,18 \pm 5,54$ \\
\hline
\end{tabular}

Keterangan: $\varnothing$ diameter pohon 
Biomassa karbon mangrove melalui persamaan alometrik dari biomassa karbon spesies mangrove tertentu berdasarkan penelitian yang telah dilakukan sebelumnya. Biomassa terbesar terdapat dari spesies Rhizophora apiculata, dan Rhizophora stylosa, hal tersebut diduga bahwa kerapatan dari kedua spesies tersebut lebih besar dari spesies lain dari kedua zona.

Hasil penelitian biomassa karbon mangrove di Desa Sidodadi, Ringgung, Kabupaten Pesawaran Provinsi Lampung menunjukkan bahwa semakin besar lingkar batang dan semakin banyak pohon menunjukkan bahwa biomassa karbon semakin besar.

Tabel 7. Biomassa Karbon Mangrove pada Zona I dan Zona II di Desa Sidodadi, Ringgung, Kabupaten Pesawaran Provinsi Lampung.

\begin{tabular}{cc}
\hline Zona & Total Biomassa Karbon $(\mathrm{kg} / \mathrm{ha})$ \\
\hline I & $2.578 .104,31$ \\
II & $8.116 .765,87$ \\
\hline Total & $10.694 .870,18$
\end{tabular}

Tabel 7 Biomassa Karbon Mangrove pada Zona I dan Zona II di Desa Sidodadi, Ringgung, Kabupaten Pesawaran Provinsi Lampung menunjukkan nilai dari biomassa karbon mangrove dari kedua zona. Pada Zona II menunjukkan nilai biomassa karbon mangrove yang lebih besar tiga kali dari nilai biomassa karbon mangrove di Zona I dengan nilai biomassa karbon Zona II sebesar 8.116.765,87 kg/ha.

Analisa NDVI (Normalized Difference Vegetation Index)

Nilai NDVI pada setiap zona diambil dari semua titik koordinat kemudian dicari sebaran nilai NDVI berdasarkan nilai minimum dan nilai maksimum. Tabel 6 menjelaskan nilai sebaran NDVI berdasarkan nilai minimum dan maksimunya, kemudian penentuan tingkat kerusakan mangrove berdasarkan Kusmana (2010) dengan diambil nilai median, maka nilai NDVI dari Zona I yaitu 0,25 dan Zona II 0,378 yang memiliki kategori berturut-turut rusak dan katagori rusak sedang.

Tabel 6. Distribusi Nilai NDVI (Normalized Difference Vegetation Index) pada Zona I dan Zona II Di Desa Sidodadi, Ringgung, Kabupaten Pesawaran Provinsi Lampung

\begin{tabular}{ccc}
\hline Zona & Nilai NDVI & Median NDVI \\
\hline I & $0,0073-0,423$ & 0,25 \\
II & $0,095-0,675$ & 0,378 \\
\hline
\end{tabular}

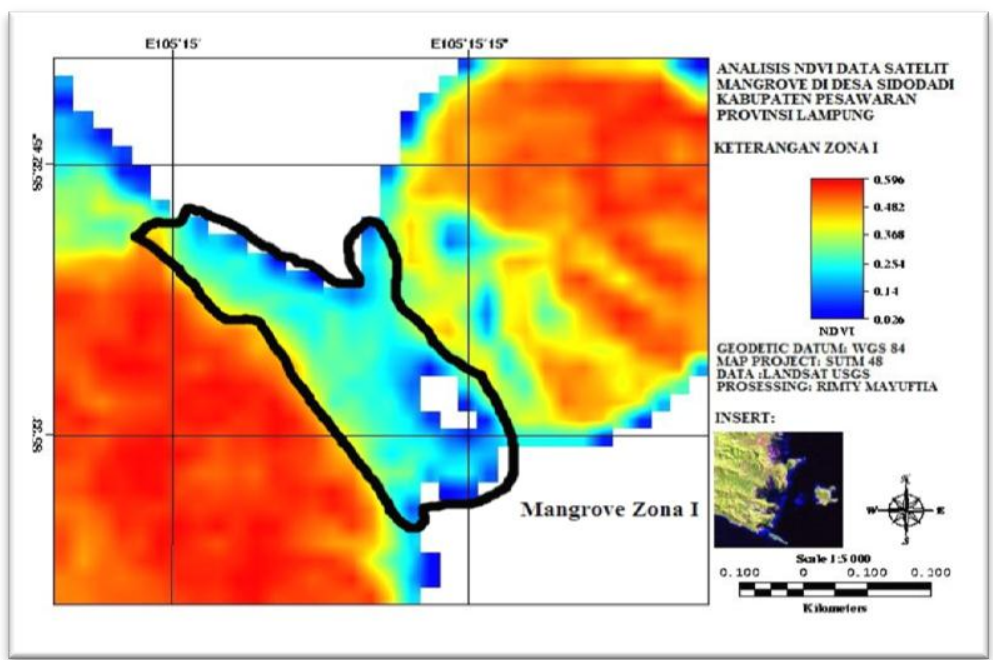

Gambar 2. Peta Distribusi Nilai Normalized Difference Vegetation Index (NDVI) Mangrove pada Zona I Di Desa Sidodadi, Ringgung, Kabupaten Pesawaran Provinsi Lampung 


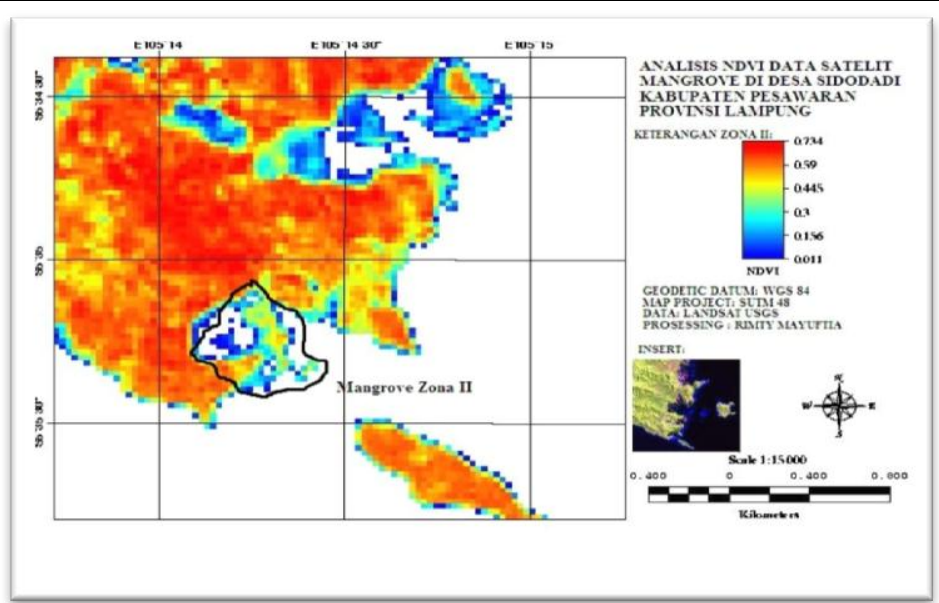

Gambar 3. Peta Distribusi Nilai Normalized Difference Vegetation Index (NDVI) Mangrove pada Zona II Di Desa Sidodadi, Ringgung, Kabupaten Pesawaran Provinsi Lampung

Hubungan antara Biomassa Karbon dan Tegakan Pohon Mangrove dengan NDVI (Normalized Difference Vegetation Index)

Tabel 7. Regresi Ganda antara Biomassa Karbon, Pohon Mangrove dengan NDVI, significance, dan correlation

\begin{tabular}{|c|c|c|c|c|c|c|}
\hline \multirow[b]{2}{*}{ Model } & \multicolumn{2}{|c|}{ Unstandardized Coefficients } & \multirow{2}{*}{$\begin{array}{c}\text { Standardized } \\
\text { Coefficients } \\
\text { Beta } \\
\end{array}$} & \multirow[b]{2}{*}{$\mathrm{t}$} & \multirow[b]{2}{*}{ Sig. } & \multirow[b]{2}{*}{$\mathrm{r}$} \\
\hline & B & Std. Error & & & & \\
\hline (Constant) & 0.195 & 0.032 & & 6.168 & 0 & \\
\hline BIOMASSA & 2.93E-06 & 0 & 0.742 & 6.321 & 0 & 0,675 \\
\hline POHON & -0.001 & 0.001 & -0.125 & -1.063 & 0.292 & 0,271 \\
\hline
\end{tabular}

Tabel 7 menunjukkan nilai significance dari biomassa yaitu 0 dan pohon sebesar 0,292. Hal tersebut menunjukkan bahwa nilai significance dari biomassa menunjukkan nilai 0 yang artinya signifikan karena kurang dari 0,05, maka ada pengaruh antara variabel biomassa karbon dan variabel NDVI. Sedangkan untuk nilai variabel pohon nilai signifikan 0,292 artinya tidak signifikan karena lebih dari 0,05. Nilai korelasi ( $r$ ) antara biomassa dengan NDVI sebesar 0,675 dan nilai $(r)$ dengan nilai 0,271 . Tabel ditulis dalam persamaan regresi yaitu $\mathrm{y}=0,195+2,93 \mathrm{E}^{-06}$ biomassa $-0,001$ pohon.

Hasil hubungan antara biomassa mangrove, pohon mangrove dengan nilai NDVI menunjukkan bahwa adanya hubungan keeratan yang kuat antara biomassa mangrove dengan nilai NDVI, maka nilai NDVI dapat digunakan untuk menuduga potensi biomassa karbon dalam suatu vegetasi mangrove. Semakin besar digital number NDVI pada vegetasi mangrove maka semakin besar pula biomassa karbon yang terkandung.

Hubungan pohon mangrove dengan nilai NDVI tidak telihat nilai yang signifikan, dan nilai korelasi yang rendah, sehingga disimpulkan digital number NDVI belum dapat menjelaskan banyaknya pohon mangrove atau kerapatan dalam suatu pantulan citra yang terekam satelit. Hal tersebut diduga citra satelit melihat secara luasan yaitu tutupan kanopi (coverage) dari suatu vegetasi mangrove sedangkan suatu nilai coverage tidak menunjukkan besaran atau banyakknya kerapatan pohon mangrove.

\section{Analisa Kerusakan Ekosistem Mangrove}

Berdasarkan baku mutu kerusakan mangrove berdasarkan hasil digital number NDVI (Normalized Difference Vegetation Index) (Kusmana, 2010) yang didapat dari pendekatan tidak langsung secara matematis menggunakan citra satelit Landsat TM, ekosistem mangrove di Desa Sidodadi, Ringgung, Kabupaten Pesawaran Provinsi Lampung, dengan nilai rerata NDVI pada Zona I sebesar 0,25 dan Zona II sebesar 0,378, maka tingkat kerusakan mangrove berturut-turut adalah rusak berat dan rusak sedang.

Perbandingan baku mutu suatu ekosistem mangrove dengan menggunakan kerapatan pohon dengan interpretasi citra menggunakan Landsat TM dalam skala peta 1:250.000 - 1:100.000, maka ekosistem mangrove di Desa Sidodadi, Ringgung, Kabupaten Pesawaran Provinsi Lampung dengan kerapatan pohon mangrove yang memiliki jumlah pohon 880 - >1100 pohon, dikategorikan sangat rapat (Departemen Kelautan dan Perikanan, Direktorat Bina Pesisir, Ditjen KPPK, 2007). Namun, bila menggunakan kriteria baku kerusakan mangrove berdasarkan Keputusan Menteri Lingkungan Hidup Nomor 201 Tahun 2004, kriteria pohon memiliki kriteria baik dengan kerapatan sedang dengan indikator terdapat jumlah pohon > 1000 pohon/ha. 
Bila melihat dari nilai NDVI yang memiliki nilai yang rendah diduga karena tempat tersebut awalnya memiliki cakupan luasan mangrove yang lebih luas, namun karena adanya kegiatan perikanan berupa tambak maka ekosistem mangrove menjadi berkurang, namun secara kerapatan mangrove di Desa Sidodadi, Ringgung, Kabupaten Pesawaran Provinsi Lampung masih baik dengan nilai kerapatan yang tergolong sangat tinggi berdasarkan analisa dari keraptan pohon dari berbagai dua kriteria dari Depatemen Kelautan dan Perikanan dan Surat Keputusan Menteri Lingkungan Hidup.

Kerusakan mangrove bisa terjadi karena kerusakan fungsi, kerusakan komposisi, dan kerusakan struktur (Hendrarto, pers.com, 2013). Kerusakan mangrove berdasarkan kedua indikator penelitan di Desa Sidodadi, Ringgung, Kabupaten Pesawaran Provinsi Lampung ini yaitu katagori kerusakan fungsi karena lahan mangrove yang sebagian telah menjadi tambak, dibuktikan dengan hasil NDVI, namun secara komposisi masih sangat baik, dibuktikan dengan kerapatan vegetasi mangrove, jenis mangrove yang bervariasi, dan diameter pohon yang tergolong pohon yang sudah tua.

Berdasarkan hasil analisa nilai NDVI dari vegetasi mangrove maka tingkat kerusakan mangrove yang tergolong sudah rusak, apabila dilihat dari nilai kerapatan sapling yang masih tergolong baik di Desa Sidodadi maka bisa menjadi acuan dari kerusakan yang sudah ada sebelumnya untuk memulihkan kembali vegetasi mangrove untuk beberapa tahun mendatang. Penanaman mangrove kembali oleh masyarakat menjadi aksi nyata dalam membantu recover bagi vegetasi mangrove di Desa Sidodadi selain pemulihan vegetasi secara alami.

Pengelolaan ekosistem mangrove di Desa Sidodadi, Ringgung, Kabupaten Pesawaran Provinsi Lampung masih harus dibenahi dengan adanya banyak tambak baik yang masih digunakan maupun yang sudah tidak digunakan kembali. Kelompok petani mangrove di Desa Sidodadi, Ringgung, Kabupaten Pesawaran Provinsi Lampung telah melakukan usaha penanaman kembali dan menjadi sumber penghasilan tambahan bagi mereka dengan menjadi petani pembibit mangrove. Kesadaran masyarakat yang tinggi untuk kelestarian ekosistem mangrove dan lingkungan pesisir, namun belum didukung sepenuhnya oleh pemerintah daerah.

\section{Kesimpulan}

Kesimpulan yang didapatkan dari penelitian ini adalah :

1. Biomassa karbon pada vegetasi mangrove di Pesisir Lampung, Desa Sidodadi, Kabupaten Pesawaran, Provinsi Lampung pada kedua zona adalah 10.694.870,18 kg/ha.

2. Tingkat kerusakan vegetasi mangrove di Pesisir Lampung, Desa Sidodadi, Kabupaten Pesawaran, Provinsi Lampung berdasarkan kriteria nilai NDVI (Normalized Difference Vegetation Index) dengan nilai pada Zona I dan Zona II berturut-turut sebesar 0,25 dan sebesar 0,378, maka tingkat kerusakan mangrove berturut-turut adalah rusak berat dan rusak sedang.

3. Hubungan Biomassa Karbon Mangrove dan Tegakan Pohon Mangrove terhadap Nilai NDVI (Normalized Difference Vegetation Index) adalah bahwa nilai NDVI dapat menduga biomassa karbon mangrove, tetapi tidak dapat digunakan untuk menentukan nilai dari kerapatan pohon mangrove.

\section{Ucapan Terima Kasih}

Ucapan terima kasih ditujukan kepada Bapak Untung selaku Ketua Petani Mangrove Desa Sidodadi, Kabupaten Pesawaran Provinsi Lampung yang telah membantu penelitian ini dan berdiskusi mengenai mangrove khususnya Provinsi Lampung. Ucapan terima kasih ditujukan pula kepada Drs. Ign. Boedi Hendrarto, M.Sc, Ph.D dan Prof. Dr. Ir. Agus Hartoko, M.Sc atas bimbingannya dalam penyusunan penelitian ini.

\section{Daftar Pustaka}

Clogh, B.F. dan K. Scott. 1989. Allometric Relationship for Estimating Above-Ground Biomassa in Six Mangrove Species. Forest Ecology and Management.

English, S., C. Wilkinson, dan V. Barker. 1997. Survey Manual for Tropical Marine Resources. Mc Craw Publication. Australia.

Hadi, S. 1984. Metodologi Reserch: Untuk Penulisan Paper, Skripsi, Thesis, dan Disertasi. Jilid 1. Fakultas Psikologi Univ. Gadjah Mada. Yogyakarta.

Hartoko, A dan M. Helmi. 2008. Aplikasi Inderaja dan SIG Untuk Analisa dan Pengelolaan Wilayah Pesisir dan Ekosistem Laut. Vol 1. Semarang.

Nazir, A. 1983. Metode Penelitian. Ghalia Indonesia. Jakarta.

Noor, R. Y., Khazali. M., dan I.N.N, Suryadiputra. 2006. Panduan Pengenalan Mangrove di Indonesia. Wetlands International - Indonesia Programme. Cet. II.

Kementerian Negara Lingkungan Hidup No. 201 Tahun 2004. Kriteria Baku dan Pedoman Penentuan Kerusakan Mangrove. 
Kementerian Kelautan dan Perikanan. 2007. Pengelolaan Ekosistem Mangrove. Direktorat Bina Pesisir, Ditjen KPPK Republik Indonesia. Jakarta.

Komiyama, A., S. Poungparn, and S. Kato. 2005. Common Allometric Equation for Estimating The Tree Weight of Mangroves, J. Trop, Ecol., 21, 471-477.

Kusmana, C. 2010. Tingkat Kerusakan Mangrove berdasarkan Nilai NDVI dan Kerapatan Kanopi. Jurnal Respon Mangrove Terhadap Pencemaran. Dept. Silvikultur, Fakultas Kehutan IPB.

Muller-Dumbois, D. dan H. Ellenberg. 1974. Aims and Methods of Vegetation Ecology. John Wiley \& Sons. London.

Siregar, C. A, dan I.W.S. Dharmawan. 2009. Biomassa Karbon Pada Hutan Tanaman Mangrove. Laporan Hasil Penelitian. Pusat Penelitian Hutan dan Konservasi Alam. Bogor.

Sudjana. 1992. Teknis Analisis Regresi dan Korelasi Bagi Para Peneliti. Tarsito. Bandung.

Temilola. E. Fatoyinbo., Marc Simard., Robert. A. Washington-Allen., and H. A, Shugart. 2007. Landscapscale Extent, Height, Biomass, and Carbon Estimation of Mozambique's Mangrove Forest with Landsat ETM+ and Shuttle Radar Topography Mission elevation data. American Geophysical Union Copyright 2008. 